\title{
David Oliver: End of life care in hospital is everyone's business
}

\section{David Oliver consultant in geriatrics and acute general medicine}

Berkshire

Palliative care: do we need more specialist clinicians, or more generalist staff better trained in it? My answer is both.

About 500000 people die each year in England and Wales. ${ }^{1}$ Yet the United Kingdom has only an estimated 519 specialist palliative medicine consultants and fewer than 5000 crucial specialist palliative care nurses. ${ }^{21}$

A national audit of end of life care in hospital by the Royal College of Physicians found a median of one palliative medicine consultant and five nurse specialists for every 1000 adult hospital beds. ${ }^{3}$

Some of us will die suddenly. Others may have only weeks to prepare after an unexpected terminal diagnosis, but most will die with or from long term conditions. Multiple contacts with health and care practitioners give us many opportunities to discuss and plan for our deaths.

Despite concerted campaigns to improve care in the last year of life and get more people to make advance plans, these opportunities are missed. ${ }^{4}$ Only $4 \%$ of 9000 patients in the hospital audit had any form of advance plan made before admission. $^{3}$

Nearly half of us die in hospital. ${ }^{6}$ We don't have sufficient hospice places, staff, or funding to support everyone to die in other settings. Some people may wish to stay in hospital at the end, ${ }^{7}$ and a death in hospital need not be a bad one. We have-in the words of one campaign - "one chance to get it right." 8 And, despite very poor experiences reported by, for instance, the NHS Ombudsman, ${ }^{9}$ we seem to get it right more often than not.

The latest national survey found that two thirds of 21000 bereaved people thought that the quality of care had been outstanding, excellent, or good, although one in 10 rated it as poor. ${ }^{10}$ Hospices offered the best experience overall, and symptom control was easier to achieve in hospital than at home.

Many recently qualified doctors report feeling underprepared for end of life care

However, the Royal College of Physicians audit found major gaps in documenting basic aspects of care in patients whose death could reasonably be anticipated. ${ }^{4}$ These included patients or loved ones discussing their own concerns and choices; spiritual care; clear plans around eating, drinking, artificial nutrition, and hydration; and control of common symptoms. Only a third of hospitals had face to face specialist palliative care seven days a week. Many patients were unable to see specialist doctors or nurses.

Many recently qualified doctors report feeling underprepared for end of life care. ${ }^{11}$ The National Council for Palliative Care and Marie Curie have highlighted similar training gaps among nurses. ${ }^{12}$

Without substantial and un-promised increases in staff numbers in specialist palliative medicine and nursing, getting the basics right must be everyone's business.

\section{Competing interests: See www.bmj.com/about-bmj/freelance-} contributors/david-oliver.

Provenance and peer review: Commissioned; not externally peer reviewed.

National Council for Palliative Care. Staff prepared to care? Capacity and competence in the end of life care workforce. May 2016 www.ncpc.org.uk/sites/default/files/workforce report_May_2016.pdf.

2 Royal College of Physicians of London. Edinburgh and Glasgow. Census of consultant physicians and higher specialty trainees in the UK 2014-15. 2015 https://www.rcplondon. ac.uk/projects/outputs/2014-15-census-uk-consultants-and-higher-specialty-trainees.

3 Royal College of Physicians of London. Marie Curie. End of life care audit. Dying in hospital: executive summary. May 2014. https://www.rcplondon.ac.uk/projects/outputs/ national-care-dying-audit-hospitals.

$4 \quad$ NHS England. Commissioning person centred end of life care: a toolkit for health and social care. Apr 2016. https://www.england.nhs.uk/wp-content/uploads/2016/04/nhsiqcomms-eolc-tlkit-.pdf.

5 National Palliative and End of Life Care Partnership. Ambitions for palliative and end of life care: a national framework for local action 2015-2020. 2014. A http:// endoflifecareambitions.org.uk/wp-content/uploads/2015/09/Ambitions-for-Palliative-andEnd-of-Life-Care.pdf.

6 Office for National Statistics. Deaths registered in England and Wales (series DR): 2014 Tables 1-4 and 6-14 (Excel sheet $1051 \mathrm{~kb}$ ) (table 12). Deaths registered by age, sex and selected underlying cause of death. 2015. Available at: www.ons.gov.uk/ peoplepopulationandcommunity/birthsdeathsandmarriages/deaths/bulletins/ deathsregisteredinenglandandwalesseriesdr/2015-11-09.

7 Pollock K. Is home always the best and preferred place of death?BMJ 2015;351:h4855. doi:10.1136/bmj.h4855 pmid:26446163.

8 Leadership Alliance for the Care of Dying People. One chance to get it right: improving people's experience of care in the last few hours and days of life. Jun 2014. https://www. 
gov.uk/government/uploads/system/uploads/attachment_data/file/323188/One_chance to_get_it_right.pdf.

9 Parliamentary and Health Service Ombudsman. Dying without dignity: investigations by the Parliamentary and Health Service Ombudsman into complaints about end of life care. www.ombudsman.org.uk/_data/assets/pdf_file/0019/32167/Dying_without_dignity_report. pdf.

10 National Survey of Bereaved People (VOICES). 2015 report. www.ons.gov.uk peoplepopulationandcommunity/healthandsocialcare/healthcaresystem/bulletins/ nationalsurveyofbereavedpeoplevoices/england2015.

11 Bowden J, Dempsey K, Boyd K, Fallon M, Murray SA. Are newly qualified doctors prepared to provide supportive and end-of-life care? A survey of Foundation Year 1 doctors and consultants. J R Coll Physicians Edinb 2013;43:24-8. doi:10.4997/JRCPE.2013.105. pmid: 23516686.

12 Marie Curie. Triggers for palliative care: improving access for people with diseases other than cancer. Jun 2015. https://www.mariecurie.org.uk/globalassets/media/documents/ policy/policy-publications/june-2015/triggers-for-palliative-care-full-report.pdf.

Published by the BMJ Publishing Group Limited. For permission to use (where not already granted under a licence) please go to http://group.bmj.com/group/rights-licensing/ permissions 